\title{
UPAYA PENINGKATAN PRODUKSI SUSU SAPI PERAH DENGAN PEMBERIAN VITAMIN ADE DAN OBAT CACING
}

\author{
Improving Dairy Cow Productivity By Vitamin A, D, E And Antihelminthic \\ Addition
}

\author{
Galuh Chandra Agustina*1), Viski Fitri Hendrawan ${ }^{1)}$, Desi Wulansari1), Yudit Oktanella ${ }^{1)}$ \\ 1) Fakultas Kedokteran Hewan, Universitas Brawijaya, Jl. Puncak Dieng, Kunci, Kalisongo, Dau, Malang, Jawa \\ Timur, Indonesia 65151 \\ E-mail: ca.galuh@gmail.com
}

Diterima Pasca Revisi: 27 Februari 2020

Layak Diterbitkan: 1 Maret 2020

\begin{abstract}
ABSTRAK
Saat ini produksi susu sapi dalam negeri baru bisa memasok tidak lebih dari $21 \%$ kebutuhan konsumsi susu, sisanya 79\% berasal dari impor susu sapi. Keberhasilan beternak sapi perah untuk dapat meningkatkan produktivitas adalah kesehatan ternak. Gangguan kesehatan pada ternak dapat menyebabkan penurunan produktivitas sehingga menyebabkan kerugian ekonomi di bidang peternakan. Helminthiasis merupakan penyakit yang sangat sering terjadi pada ternak. Helminthiasis disebabkan oleh infeksi cacing dalam tubuh ternak. Lingkungan yang lembab dan sanitasi yang kurang baik, menjadi penyebab infeksi cacing. Telur-telur cacing akan mencemari pakan dan minum ternak, sehingga ikut tertelan ke dalam saluran pencernaan. Di dalam saluran pencernaan cacing menetas dan berkembang dengan mengambil nutrisi dari saluran pencernaan dengan cara merusak mukosa saluran pencernaan. Rusaknya mukosa saluran pencernaan mengakibatkan gangguan penyerapan nutrisi ternak. Pemberian obat cacing secara rutin perlu dilakukan untuk meningkatkan kesehatan dan produktivitas ternak. Obat cacing bekerja dengan cara membunuh atau mengurangi cacing dalam lumen usus dan atau jaringan tubuh. Obat cacing yang digunakan adalah albendazole yang efektif untuk semua spesies cacing. Obat cacing diberikan secara per oral kepada pedet dan sapi dewasa yang tidak bunting sebanyak 97 ekor. Pemberian obat cacing dan vitamin memberikan dampak positif terhadap peningkatan produksi susu sapi sebanyak $12 \%$ dari 10 ekor sapi yang diambil secara sampling.
\end{abstract}

Kata Kunci: Albendazole, helmintiasis, obat cacing, sapi perah

How to Cite:

Agustina, G.C., Hendrawan, V.F., Wulansari D., \& Oktanella D. (2020). Upaya Peningkatan Produksi Susu Sapi Perah Dengan Pemberian Vitamin Ade dan Obat Cacing. Jurnal Nutrisi Ternak Tropis 3 (1) 1-6
*Corresponding author:

Galuh Chandra Agustina

Email: ca.galuh@gmail.com

Fakultas Kedokteran Hewan, Universitas Brawijaya, Jl. Puncak Dieng, Kunci, Kalisongo, Dau, Malang, Jawa Timur, Indonesia 65151 


\section{ABSTRACT}

The cow milk production in the country could only supply no more than $21 \%$, milk consumption needs the rest $79 \%$ to originate from imports dairy cows (Kementan, 2016). Health of dairy cows is one of the keys to success in efforts to increase productivity. The disease in livestock can cause a decrease in the rate of productivity cattle to cause harm economic. Helminthiasis is a disease in livestock. happens very oftenHelminthiasis is the result of infectious disease. worms in the body. A moist environment and sanitation, poor the level of infection high. Eggs of worms will pollute, fodder and flocks and also ingested into the digestive tract. In the alimentary canal, worms hatch and growing by taking nutrients from the digestive tract in a destructive manner the mucosa of the digestive. Mucous damage to the digestive tract resulting in interference absorption of nutrients cattle. The prevention and control helminthiasis in livestock needs to be done to improve health and productivity cattle, one of them is the way of medicine worms. A worm used to root out or reduce worm in lumen intestines and or tissues of the body. A worm used is albendazole for all species of worms. A worm provided in peroral to calf and cattle adult 97 dairy cows. Administering medication worm and vitamin have a positive impact on the increased production of dairy cattle as many as $12 \%$ of 10 cows taken by sampling.

Keywords: Albendazole, dairy cow, helminthic, helmintiasis

\section{PENDAHULUAN}

Tingginya impor susu dari luar negeri mengakibatkan kerugian langsung pada peternakan sapi perah di Indonesia. Melihat potensi sumber daya alam Indonesia yang besar bagi pengembangan agribisnis persusuan, sangat ironis jika sebagian besar dari kebutuhan susu Indonesia harus impor. Dengan demikian, pemerintah dan stakeholder perlu berupaya keras meningkatkan pangsa pasar para pelaku pasar domestik dalam agribisnis persusuan Indonesia (Kementrian, 2016). Kesehatan ternak sapi merupakan salah satu kunci keberhasilan dalam usaha peningkatan produktivitas ternak. Timbulnya penyakit pada ternak dapat menyebabkan penurunan produktivitas ternak sehingga menyebabkan kerugian ekonomi di bidang peternakan. Diantara sekian banyak penyakit hewan di Indonesia, penyakit parasit atau helminthiasis masih kurang mendapat perhatian dari para peternak. Helminthiasis merupakan penyakit akibat infeksi cacing dalam tubuh. Penyakit parasit biasanya tidak mengakibatkan kematian ternak, namun menyebabkan kerugian berupa penurunan kondisi badan, penurunan produksi susu pada ternak dewasa, dan hambatan pertumbuhan pada ternak muda. Salah satu penyakit parasit yang sangat merugikan adalah penyakit nematoda gastrointestinal yaitu sekelompok cacing nematoda yang menginfeksi saluran pencernaan ternak (Andrianty, 2015). Program pencegahan dan pengendalian helminthiasis pada ternak perlu dilakukan untuk meningkatkan kesehatan dan produktivitas ternak, salah satunya dengan cara pemberian obat cacing. Obat cacing digunakan untuk membasmi atau mengurangi cacing dalam lumen usus dan atau jaringan tubuh. Peternakan sapi perah umumnya tergabung dalam suatu koperasi. Perhatian dan pengetahuan koperasi terhadap penyakit helminthiasis saluran cerna akan mempengaruhi tinggi rendahnya kasus infeksi cacing pada sapi perah di kelompok ternak di wilayah koerasi tersebut (Zalizar, 2017).

\section{MATERI DAN METODE}

Sasaran kegitana ini adalah seluruh kolompok ternak sapi perah di KUD Kerta Jaya desa Medowo, Kecamatan Kandangan, 
Kota Kediri. Kegiatan berupa pelayanan kesehatan ternak gratis, berupa pemeriksaan kesehatan secara umum gratis, konsultasi kesehatan ternak gratis, pemberian vitamin A, D, dan E pada ternak serta pengendalian penyakit helminthiasis dengan pemberian obat cacing. Memberikan penyuluhan cara pemeliharaan ternak sapi perah yang baik untuk meningkatkan produksi susu.

\section{HASIL DAN PEMBAHASAN}

Kegiatan pengabdian kepada masyarakat ini dilaksanakan di kelompok ternak di KUD Kerta Jaya desa Medowo, Kecamatan Kandangan, Kota Kediri. Ternak sapi yang sehat merupakan kunci keberhasilan dalam usaha peningkatan produktivitas ternak. Penurunan produktivitas ternak berdampak pada kerugian ekonomi yang disebabkan karena adanya gangguan kesehatan ternak.

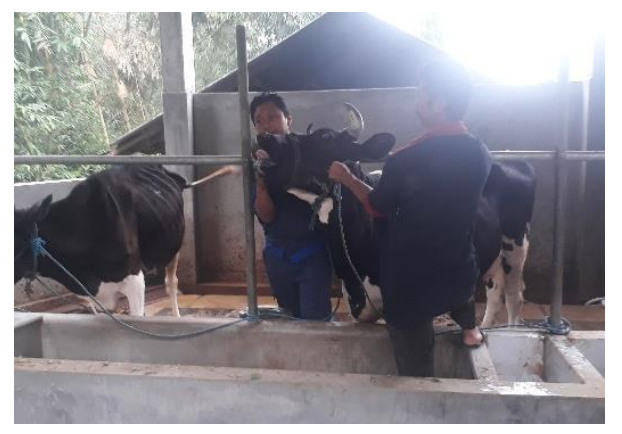

Rendahnya tingkat kesadaran masyarakat berpengaruh pada manajemen pemeliharaan dan kesehatan hewan.

Oleh karena itu, civitas akademika Fakultas Kedokteran Hewan Universitas Brawijaya ingin memberikan kontribusi berupa pelayanan kesehatan ternak kepada masyarakat petani peternak. Cakupan kegiatan yang dilakukan antara lain sebagai upaya untuk meningkatkan kesejahteraan masyarakat petani peternak melalui pelayanan kesehatan hewan meliputi konsultasi kesehatan hewan, pemberian vitamin $\mathrm{ADE}$, dan obat cacing.

Pelaksanaan program pelayanan kesehatan dilakukan dalam waktu satu hari di desa terkait dan akan dilaksanakan evalusi kepada masyarakat petani peternak di desa terkait untuk melihat perkembangan dari pelaksanaan program ini peningkatan kesadaran masyarakat terhadap kesehatan hewan setelah dilaksanakan program ini.

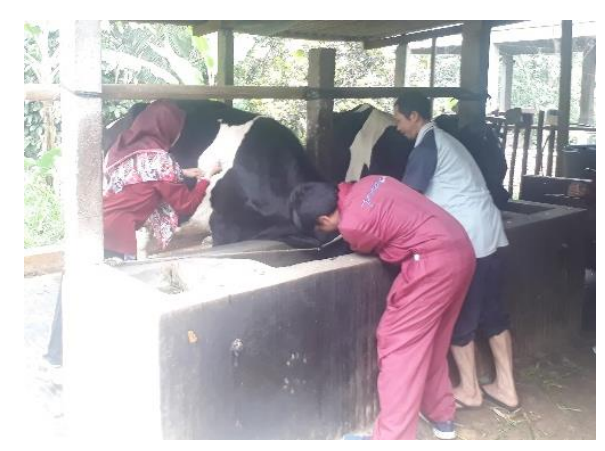

Gambar 1. Pemberian obat cacing (kiri) serta vitamin A, D, dan E pada sapi perah (kanan).

Tanpa kelengkapan nutrisi yang baik dan dalam jumlah memadai maka meskipun ternak tersebut merupakan bibit unggul akan kurang dapat memperlihatkan keunggulanya (Akoso, 2012). Kelengkapan zat gizi dalam makanan ternak runimansia akan dapat mempercepat pertumbuhan dan produktivitas. Salah satu nutrisi yang berpengaruh dalam performa ternak adalah vitamin. Beberapa jenis vitamin yang sangat dibutuhkan untuk daya tahan tubuh sapi dan pertumbuhan vitamin A, D, dan E. Vitamin memainkan peran penting dalam metabolisme sel.
Vitamin dapat dibentuk dalam tubuh hewan yang memamah biak seperti sapi, sehingga kemungkinan terjadinya kekurangan vitamin sangat kecil, kecuali pada kasus kekurangan pakan atau kualitas pakan yang kurang baik. Pemberian vitamin pada sapi memiliki fungsi masing-masing. Vitamin A pada sapi dapat mencegah masalah kesehatan mata, meningkatkan sistem imun, juga berperan penting dalam pertumbuhan dan perkembangan sel serta menjaga kesehatan kulit. Ternak yang kekurangan hijauan maka perlu diberikan vitamin A. 
Kekurangan vitamin A menyebabkan gangguan dan berkurangnya fungsi mata, infeksi saluran pernapasan, menurunnya daya tahan tubuh, kulit dan bulu yang tidak sehat dan anak yang lahir lemah atau mati. Peran vitamin D pada ternak sapi untuk memperkuat tulang, karena vitamin D membantu penyerapan kalsium oleh tubuh. Vitamin D disentesa dalam jaringan tubuh dengan bantuan sinar matahari, karena jaringan di bwah kulit terdapat pro-vitamin D yang apabila terkena sinar matahari akan terbentuk vitamin D. Pada sapi perah Membutuhkan kalsium 2 kali lebih banyak dari sapi potong karena sapi perah membutuhkan kalsium untuk produksi susu yang sangat banyak.

Ternak yang kekurangan vitamin D akan mengakibatkan pertumbuhan terhambat, seperti pertumbuhan gigi dan tulang terganggu dan tidak maksimal sehingga mudah rusak. Pada sapi perah yang produktif dapat menyebabkan sapi ambruk karena kekurangan kalsium. Vitamin E pada ternak sapi sebagai antioksidan yang dapat melindungi sel dari kerusakan dan penting untuk kesehatan sel darah merah. Gangguan pada reproduksi dapat terjadi pada ternak sapi betina yang kekurangan vitamin $\mathrm{E}$, serta gangguan pada saraf dan otot.

Vitamin E berperan pada kesehatan ambing sapi perah (Yanuarto dkk., 2018).
Pemberian pada tubuh sapi sebaiknya tidak terlalu berlebihan, karena vitamin yang berlebih maka akan dibuang melaui urine. Pemberian vitamin yang tepat akan menghasilkan produktifitas sapi perah yang lebih baik. Pemberian vitamin A, D, dan E secara injeksi dengan dosis $10 \mathrm{ml} /$ ekor sapi. Pemberian obat cacing perlu dipertimbangkan diantaranya adalah jenis obat cacing yang tepat untuk cacing yang menginfeksi ternak tersebut, misalnya obat cacing yang efektif untuk cacing nematoda belum tentu efektif untuk cacing trenatoda. Albendazole adalah obat yang dipilih untuk pengobatan dan pencegahan penyakit parasit (cacing) pada kegiatan pengabdian kepada masyarakat ini.

Obat-obat tersebut tersedia secara luas disebagian besar sistem pelayanan kesehatan sebagai pengobatan kuratif dari kasus-kasus klinis selama bertahun-tahun. Menurut Muda (2015), albendazole mempunyai efektivitas $100 \%$ dalam menurunkan jumlah telur cacing. Obat cacing diberikan kepada pedet sapi dan sapi dewasa yang tidak bunting. Dikarenakan jika pemberian obat cacing pada ternak yang bunting akan memiliki efek samping dari kandungan obat tersebut yang dapat mengakibatkan abortus pada ternak oleh sebab itu obat cacing hanya diberikan pada ternak sapi yang tidak bunting.

Tabel 1.Perbandingan hasil produksi susu

\begin{tabular}{ccc}
\hline $\begin{array}{c}\text { Produksi sebelum pemberian } \\
\text { obat cacing dan vitamin }\end{array}$ & $\begin{array}{c}\text { Produksi sesudah pemberian obat } \\
\text { cacing dan vitamin }\end{array}$ & Prosentase \\
\hline 10,6 & 11,8 & $11 \%$ \\
10,6 & 12 & $13 \%$ \\
12,7 & 13,7 & $8 \%$ \\
10,8 & 12,8 & $19 \%$ \\
10,8 & 11,7 & $8 \%$ \\
12 & 13 & $8 \%$ \\
10,8 & 12,3 & $14 \%$ \\
9,3 & 12,3 & $32 \%$ \\
12 & 12,3 & $3 \%$ \\
10,6 & 11,1 & $5 \%$ \\
\hline
\end{tabular}


Pada kegiatan pengabdian masyarakat kali ini mendapatkan respon yang baik dari para kelompok ternak yang bisa dilihat dari jumlah ternak yang memperoleh pengobatan cacing gratis pada pengabdian kepada masyarakat ini yaitu sebanyak 97 ekor sapi. Obat cacing dberikan langsung kepada sapi secara per oral, juga menyarankan kepada peternak untuk secara rutin setiap 6 bulan sekali menberikan obat cacing.

Demikian pula menyarankan untuk secara rutin setiap hari membersihkan kandang dari kotoran sapi, supaya tidak terinfeksi cacing kembali. Pemberian tambahan vitamin dan obat cacing efektif dapat meningkatkan produksi susu. Hal ini terbukti dari data beberapa peternak yang telah di berikan obat cacing dan vitamin menunjukkan peningkatan produksi susu yang di tunjukkan dengan tabel 1 .

Data pada tabel 1 menunjukkan adanya peningkatan dari produksi susu dari sapi yang telah di beri obat cacing dan vitamin yaitu rata-rata total $12 \%$ dari 10 ekor sapi yang diambil sebagai data. Hal ini sesuai dengan pernyataan Menurut Hidayati dan Hendraningsih (2004) bahwa tambahan mineral vitamin dapat membantu meningkatkan palatabitas konsumsi dan metabolisme pakan, sehingga dapat meningkatkan produksi dan kualitas susu.

\section{KESIMPULAN DAN SARAN}

Pelaksanaan pengabdian kepada masyarakat pada kelompok peternak di desa Medowo, Kecamatan Kandangan, Kota Kediri dilakukan 1 hari yauti pelayanan kesehatan hewan dengan pemberian vitamin A, D, dan E, dan pemberian obat cacing secara gratis. Pemberian vitamin A, D, dan E pada sapi sebanyak 73 ekor dengan volume pemberian sebanyak $10 \mathrm{ml} /$ ekor sapi dewasa.

Obat cacing yang digunakan adalah albendazole yang efektif untuk semua spesies cacing. Pemberian obat cacing pada pedet sapi dan sapi dewasa yang tidak bunting sebanyak 97 ekor sapi. Pemberian obat cacing dan vitamin memberikan dampak positif terhadap peningkatan produksi susu sapi sebanyak $12 \%$ dari 10 ekor sapi yang diambil secara sampling.

\section{DAFTAR PUSTAKA}

Akoso, B. (2012). Budidaya Sapi Perah (1st ed.). Surabaya: Airlangga Unversity Press.

Andrianty, V. (2015). Kejadian Nematodiasis Gastrointestinal pada Pedet Sapi Bali di Kec. Marioriwawo Kab. Soppeng. Universitas Hasanuddin. Makassar.

Balai Pengkajian Teknologi Pertanian. (2010). Petunjuk Praktis Manajemen Pencegahan dan Pengendalian Penyakit pada Ternak Sapi. NTB.

Hidayati, A., Hendraningsih, L., \& Prihantini, I. (2004). Pemanfaatan "biolacta" sebagai suplement vitamin mineral pada pakan dalam upaya peningkatan produksi susu sapi perah PFH di Wilayah KUD Dau. Jurnal Dedikasi, 1(2), 26-32.

Kementerian Pertanian. (2016). Outlook Susu Subsektor Peternakan.

Larasati, H. (2016). Prevalensi Cacing Saluran Pencernaan Sapi Perah pada Peternakan Rakyat di Provinsi Lampung. Universitas Lampung.

Muda, I. (2015). Efektivitas Albendazole terhadap Infestasi Cacing pada Pedet Sapi Perah. Balai Besar Pelatihan Peternakan (BBPP). Batu.

Paramita, R., Ernawati, R., \& Koesdarto, S. (2017). Prevalensi helminthiasis saluran pencernaan melalui pemeriksaan feses pada sapi di lokasi 
pembuangan akhir (LPA) Kecamatan

Benowo Surabaya. Journal of Parasite Science, 1(1), 23-32.

Sudono, A., Rosdiana, F., \& Setiawan, B. (2008). Beternak Sapi Perah Secara Intensif. Depok: Agromedia Pustaka.

Yanuartono, Y.-, Nururrozi, A., Indarjulianto, S., Purnamaningsih, H., \& Haribowo, N. (2018). Review:
Kejadian mastitis dan kaitannya dengan vitamin dan Trace Mineral $\mathrm{Cu}$, Zn, Se. Jurnal Ilmu-Ilmu Peternakan, 28(3), 265-287. https://doi.org/10.21 776/ub.jiip.2018.028.03.10

Zalizar, L. (2017). Helminthiasis saluran cerna pada sapi perah. Jurnal Ilmu-Ilmu Peternakan, 27(2), 1-7. https://doi. org/10.21776/ub.jiip.2017.027.02.01 